\title{
THE DEMOGRAPHIC AND LABOR MARKET CONDITIONS OF RURAL MUNICIPALITIES IN THE KUJAWSKO-POMORSKIE VOIVODESHIP
}

\author{
Mateusz Jankiewicz ${ }^{\bowtie}$ \\ Nicolaus Copernicus University in Toruń, Poland
}

\begin{abstract}
The purpose of this paper was to assess the impact of demographic conditions on the labor market situation in the Kujawsko-Pomorskie voivodeship, considering the spatial dependencies prevailing in the municipality system in 2004-2015. The problem of reducing inequalities in the voivodeship's labor market was also addressed. According to the Development Strategy of the Kujawsko-Pomorskie voivodeship until 2020, the main objective is to improve the competitiveness of the voivodeship's economy which would result in increased employment, especially in the region's rural areas. This aspect of development may be affected by demographic processes (e.g. changes in the share of the working-age population in the total population). The labor market and the demographic situation in the region under consideration were assessed based on the spatial taxonomic measure of development. Panel data models were evaluated to verify the relationships between the examined aspects of regional development. Supporting the analysis was a labor market convergence model developed to verify the hypothesis of inequalities reduction in the labor market.
\end{abstract}

Keywords: labor market, demographic situation, spatial taxonomic measure of development, $\beta$-convergence

\section{INTRODUCTION}

One of the three productive inputs, labor is particularly important in rural areas. Rural labor trends are the basis for the region's sustainable development. Compared to other voivodeships, Kujawsko-Pomorskie has demonstrated poor levels of development on the labor market in recent years. As regards recent unemployment figures, it has been ranked at the bottom of the voivodeships' list. The situation in the regional labor market is determined by many aspects, including demographic factors.

The EU Directives require the member states to pursue socio-economic cohesion within and across them. Regional cohesion is about providing equal opportunities in all aspects of social life to both urban and rural residents; such a requirement is also imposed by the authorities of the Kujawsko-Pomorskie voivodeship. Poor labor market conditions and unfavorable demographic changes in the voivodeship were emphasized in numerous strategies, including: the Strategy for the Development of the Kujawsko-Pomorskie voivodeship until 2020; 2020+ Modernization Plan and the Social Policy Strategy for the Kujawsko-Pomorskie voivodeship until 2020 , adopted by the authorities to improve the conditions for regional development in social and economic aspects.

Because unemployment usually affects young people (Danecka, 2013), more and more jobs need to be created. The unemployment and the number of enterprises are the key characteristics of the labor market situation. While the growing working-age population may be responsible for the deterioration in the labor market, the ageing process could have a positive effect on its formation.

\footnotetext{
$\bowtie$ MSc Mateusz Jankiewicz, Department of Econometrics and Statistics, Nicolaus Copernicus University in Torun, 11 Gagarina St., 87-100 Toruń, Poland, e-mail: mateuszj@doktorant.umk.pl, https://orcid.org/0000-0002-4713-778X
} 
The purpose of this study was to assess the influence of demographic conditions on the labor market situation in the Kujawsko-Pomorskie voivodeship, considering the spatial dependencies in 2004-2015.

\section{MATERIAL AND METHODS}

\section{Data}

The analysis was carried out at NUTS-5 spatial aggregation level. The variables that characterize the labor market and demographic situation, together with the nature of their impact, are listed in Table 1. Of all the data available at a fixed level of aggregation, the above are considered to be the most important determinants for these survey areas. The data was retrieved from the Polish Central Statistical Office (GUS) database.

The situation in different regions was examined using the spatial taxonomic measure of development. On that basis, the municipalities were ranked by condition of the examined socio-economic dimensions, starting from the best performing ones. In addition, the impact of demographic conditions on labor market measurement was subject to further analysis using panel data model estimates with fixed effects. Finally, the $\beta$-convergence model was estimated to determine the significance of the reduction of labor market inequalities across the municipalities of the voivodeship under consideration.

Three hypotheses were formulated in this study. The first one is that in the Kujawsko-Pomorskie voivodeship, urban municipalities demonstrate better labor market conditions than rural and urban-rural municipalities. The second hypothesis is that a significant relationship exists between the determinants of the dimensions under review. The last one is that labor market inequalities across the municipalities located in the Kujawsko-Pomorskie voivodeship have been significantly reduced.

\section{Spatial taxonomic measure of development}

The spatial taxonomic measure of development is a concept that has already been addressed in Polish literature (Antczak, 2013; Pietrzak, 2014; Sobolewski et al., 2014). However, it may be structured in various ways. A systematized overview of the synthetic spatial development measure was provided by Kuc (2017) who identified the advantages and disadvantages of each approach. In this study, the formula proposed by Pietrzak (2014) was used.

Initially, spatial autocorrelation was assessed for each variable using the Moran's test based on the following statistic (Suchecki, 2010):

$$
I=\frac{1}{\sum_{i=1}^{n} \sum_{j=1}^{n} w_{i j}} \cdot \frac{\sum_{i=1}^{n} \sum_{j=1}^{n} w_{i j}\left[y_{i}-\bar{y}\right]\left[y_{i}-\bar{y}\right]}{\frac{1}{n} \sum_{i=1}^{n}\left[y_{i}-\bar{y}\right]^{2}}=\frac{n}{S_{0}} \cdot \frac{z^{T} W z}{z^{T} z}
$$

where:

$y_{i}-$ observed value of the phenomenon in region $i$,

$z$ - column vector with entries denoted by $z_{i}=y_{i}-\bar{y}$,

$S_{0}=\sum_{i=1}^{n} \sum_{j=1}^{n} w_{i j}-$ sum of the corresponding entries of

the weights matrix,

$n$ - number of regions.

Then, for the spatial autocorrelation variables, the SAR model was estimated (Arbia, 2006):

Table 1. Set of diagnostic variables used in the study

\begin{tabular}{cl}
\hline Area & \multicolumn{1}{c}{ Variables } \\
\hline Labor market & $X_{1}$ - share of registered unemployed in the working-age population (D) \\
& $X_{2}-$ number of enterprises per 10,000 working-age population (S) \\
& $X_{3}-$ share of working population in the working-age population (S) \\
Demography & $X_{4}$ - share of pre-working-age population in total population (S) \\
& $X_{5}$ - share of working-age population in total population (S) \\
& $X_{6}-$ share of post-working-age population in total population (D) \\
& $X_{7}$ - population density (S) \\
& $X_{8}-$ number of live births per 1,000 population (S) \\
& $X_{9}-$ number of marriages per 1,000 population (S) \\
\hline
\end{tabular}

$\mathrm{S}$ - factors with a stimulating effect; $\mathrm{D}$ - factors with a restrictive effect

Source: own elaboration. 


$$
y=\rho W y+\varepsilon
$$

where $y$ is the vector of explanatory variables, $\rho$ is the spatial autoregressive parameter and $W$ is the appropriate spatial neighborhood matrix (in the study, the common-boundary adjacency matrix was used). The estimation of the spatial autoregressive parameter was then used to transform some diagnostic variables as per the following formula (Pietrzak, 2014):

$$
Z_{j}=(I-\rho W) X_{j}
$$

where $\rho$ is the spatial autoregressive parameter from the SAR model, with $X_{j}$ as the explanatory variable.

The next steps in the construction of the spatial taxonomic measure of development are the same as in the traditional taxonomic measure of development (Grabiński, 1984; Kolenda, 2006). The nature of diagnostic variables (classified as factors with a stimulating or restrictive effect) was determined. Afterwards, the diagnostic variables were standardized, and a development pattern for each variable was specified. The distance from the development pattern was calculated as a Euclidean distance. Then, the synthetic variable was determined and normalized. The values obtained represent the spatial assessment of the taxonomic development measure.

\section{Panel data models}

A cross-sectional dataset was used to estimate panel data models and to subsequently verify the demographic conditions' impact on the labor market in the Kujawsko-Pomorskie voivodeship. The following diagnostic tests were used to identify the right model: the Wald test (comparing the model estimated by the least squares method with the fixed effects model); the BreuschPagan test (the confronting model estimated by leastsquares and random-effects regression); and the Hausman test (comparing the models with fixed and random effects) (Osińska, 2007).

\section{$\beta$-convergence approach}

$\beta$-convergence occurs if areas that initially recorded lower values of the feature under consideration demonstrate faster growth rates than areas with higher initial values (Kusideł, 2013).

In order to verify the hypothesis on the reduction of labor market inequalities, the traditional $\beta$-convergence model for cross-sectional data, given by the following formula, was used (Arbia, 2006):

$$
\ln \left(\frac{y_{T, i}}{y_{0, i}}\right)=\alpha+\beta \ln \left(y_{0, i}\right)+\varepsilon_{i}
$$

where $y_{0, i}$ and $y_{T, i}$ are the spatial values of the taxonomic measure describing the condition of the labor market in region $i$ in the first and last period of this survey, respectively.

The $\beta$ parameter is used to calculate the $t_{\text {half-life }}$ value which represents the time needed to narrow the gap by half and is expressed as follows:

$$
t_{\text {half-life }}=\frac{\ln (2)}{b}
$$

where: $b=\frac{\ln (1+\beta)}{T}$ is the convergence rate.

\section{RESULTS}

Tables 2 and 3 present the list of municipalities ranked by calculated characteristics of the labor market and demographic situation in selected years of the study period. Figures 1 and 2 present the regional differences between the municipalities of the Kujawsko-Pomorskie voivodeship in values calculated for the first and last year of the survey period.

Municipalities of the Kujawsko-Pomorskie voivodeship ranked high in terms of labor market conditions. The cities offer excellent conditions for job creation, resulting in low unemployment. In most cases, rural municipalities located far away from large cities were the ones with the worst labor market conditions. The voivodeship is more diversified in terms of demography than in terms of labor market conditions. In the region under review, there were no significant disparities in demographic characteristics between urban and rural areas. Urban municipalities were both top- and bottomranked, reflecting the demographic condition of the municipalities.

The next step of this investigation was the analysis of relationships between demographic and labor market conditions. The results of the panel diagnostic test are shown in Table 4.

For reasons of interpretation, a model with fixed effects was chosen for further analysis. The dependent variable is a synthetic variable describing the situation on the labor market, a variable independent, and 
Table 2. Municipalities ranked by labor market situation; (1) - urban municipality, (2) - rural municipality, (3) - urbanrural municipality

\begin{tabular}{|c|c|c|c|c|}
\hline \multirow{2}{*}{ Rank } & \multicolumn{4}{|c|}{ Year } \\
\hline & 2004 & 2008 & 2012 & 2015 \\
\hline 1 & Lipno (1) & Brodnica (1) & Białe Błota (2) & Białe Błota (2) \\
\hline 2 & Brodnica (1) & Białe Błota (2) & Ciechocinek (1) & Lipno (1) \\
\hline 3 & Bydgoszcz (1) & Lipno (1) & Lipno (1) & Ciechocinek (1) \\
\hline 4 & Toruń (1) & Bydgoszcz (1) & Bydgoszcz (1) & Bydgoszcz (1) \\
\hline 5 & Włocławek (1) & Ciechocinek (1) & Brodnica (1) & Brodnica (1) \\
\hline 6 & Białe Błota (2) & Łysomice (2) & Toruń (1) & Toruń (1) \\
\hline 7 & Ciechocinek (1) & Włocławek (1) & Łysomice (2) & Rypin (1) \\
\hline 8 & Rypin (1) & Toruń (1) & Radziejów (1) & Eysomice (2) \\
\hline 9 & Radziejów (1) & Świecie (3) & Włocławek (1) & Wielka Nieszawka (2) \\
\hline 10 & Świecie (3) & Wielka Nieszawka (2) & Rypin (1) & Włocławek (1) \\
\hline \multicolumn{5}{|c|}{$\cdots$} \\
\hline 135 & Jeziora Wielkie (2) & Dobre (2) & Aleksandrów Kujawski (2) & Lipno (2) \\
\hline 136 & Boniewo (2) & Rojewo (2) & Choceń (2) & Kęsowo (2) \\
\hline 137 & Rogóźno (2) & Rogóźno (2) & Rojewo (2) & Choceń (2) \\
\hline 138 & Dąbrowa (2) & Wielgie (2) & Chełmno (2) & Dobre (2) \\
\hline 139 & Świecie nad Osą (2) & Boniewo (2) & Rogóźno (2) & Czernikowo (2) \\
\hline 140 & Wąpielsk (2) & Wąpielsk (2) & Lipno (2) & Wąpielsk (2) \\
\hline 141 & Kęsowo (2) & Sośno (2) & Bobrowniki (2) & Świecie nad Osą (2) \\
\hline 142 & Lipno (2) & Bobrowniki (2) & Papowo Biskupie (2) & Rojewo (2) \\
\hline 143 & Mrocza (3) & Lipno (2) & Świecie nad Osą (2) & Papowo Biskupie (2) \\
\hline 144 & Papowo Biskupie (2) & Świecie nad Osą (2) & Boniewo (2) & Boniewo (2) \\
\hline
\end{tabular}

Source: own elaboration.

Table 3. Municipalities ranked by demographic situation; (1) - urban municipality, (2) - rural municipality, (3) - urbanrural municipality

\begin{tabular}{|c|c|c|c|c|}
\hline \multirow{2}{*}{ Rank } & \multicolumn{4}{|c|}{ Year } \\
\hline & 2004 & 2008 & 2012 & 2015 \\
\hline 1 & 2 & 3 & 4 & 5 \\
\hline 1 & Brodnica (2) & Czernikowo (2) & Cekcyn (2) & Świecie nad Osą (2) \\
\hline 2 & Golub-Dobrzyń (1) & Brodnica (2) & Golub-Dobrzyń (1) & Łubianka (2) \\
\hline 3 & Lubicz (2) & Świecie nad Osą (2) & Obrowo (2) & Wąbrzeźno (2) \\
\hline
\end{tabular}


Jankiewicz, M. (2018). The demographic and labor market conditions of rural municipalities in the Kujawsko-Pomorskie voivodeship. J. Agribus. Rural Dev., 2(48), 121-128. http://dx.doi.org/10.17306/J.JARD.2018.00414

Table 3 cont.

\begin{tabular}{rllll}
\hline \multicolumn{1}{c}{2} & \multicolumn{2}{c}{3} & & \multicolumn{1}{c}{5} \\
\hline 4 & Łasin (3) & Lubicz (2) & Jeżewo (2) & Górzno (3) \\
5 & Brodnica (1) & Kamień Krajeński (3) & Świecie nad Osą (2) & Waganiec (2) \\
6 & Aleksandrów Kujawski (1) & Rogóźno (2) & Dąbrowa (2) & Dębowa Łąka (2) \\
7 & Górzno (3) & Kęsowo (2) & Mrocza (3) & Drzycim (2) \\
8 & Rypin (2) & Radziejów (1) & Brzozie (2) & Sicienko (2) \\
9 & Tłuchowo (2) & Obrowo (2) & Stolno (2) & Golub-Dobrzyń (1) \\
10 & Bartniczka (2) & Mrocza (3) & Kamień Krajeński (3) & Golub-Dobrzyń (2) \\
\hline & & & & \\
\hline 135 & Ciechocin (2) & Raciążek (2) & Koneck (2) & Baruchowo (2) \\
136 & Lubień Kujawski (3) & Jeziora Wielkie (2) & Lubień Kujawski (3) & Barcin (3) \\
137 & Dobre (2) & Skrwilno (2) & Nowe (3) & Koneck (2) \\
138 & Boniewo (2) & Lubień Kujawski (3) & Włocławek (1) & Nowe (3) \\
139 & Skrwilno (2) & Boniewo (2) & Bytó́ (2) & Skrwilno (2) \\
140 & Bydgoszcz (1) & Bytoń (2) & Bydgoszcz (1) & Ciechocin (2) \\
141 & Bytoń (2) & Bydgoszcz (1) & Raciążek (2) & Bydgoszcz (1) \\
142 & Książki (2) & Radziejów (2) & Baruchowo (2) & Włocławek (1) \\
143 & Nieszawa (1) & Nieszawa (1) & Skrwilno (2) & Boniewo (2) \\
144 & Ciechocinek (1) & Ciechocinek (1) & Ciechocinek (1) & Ciechocinek (1) \\
\hline
\end{tabular}

Source: own elaboration.
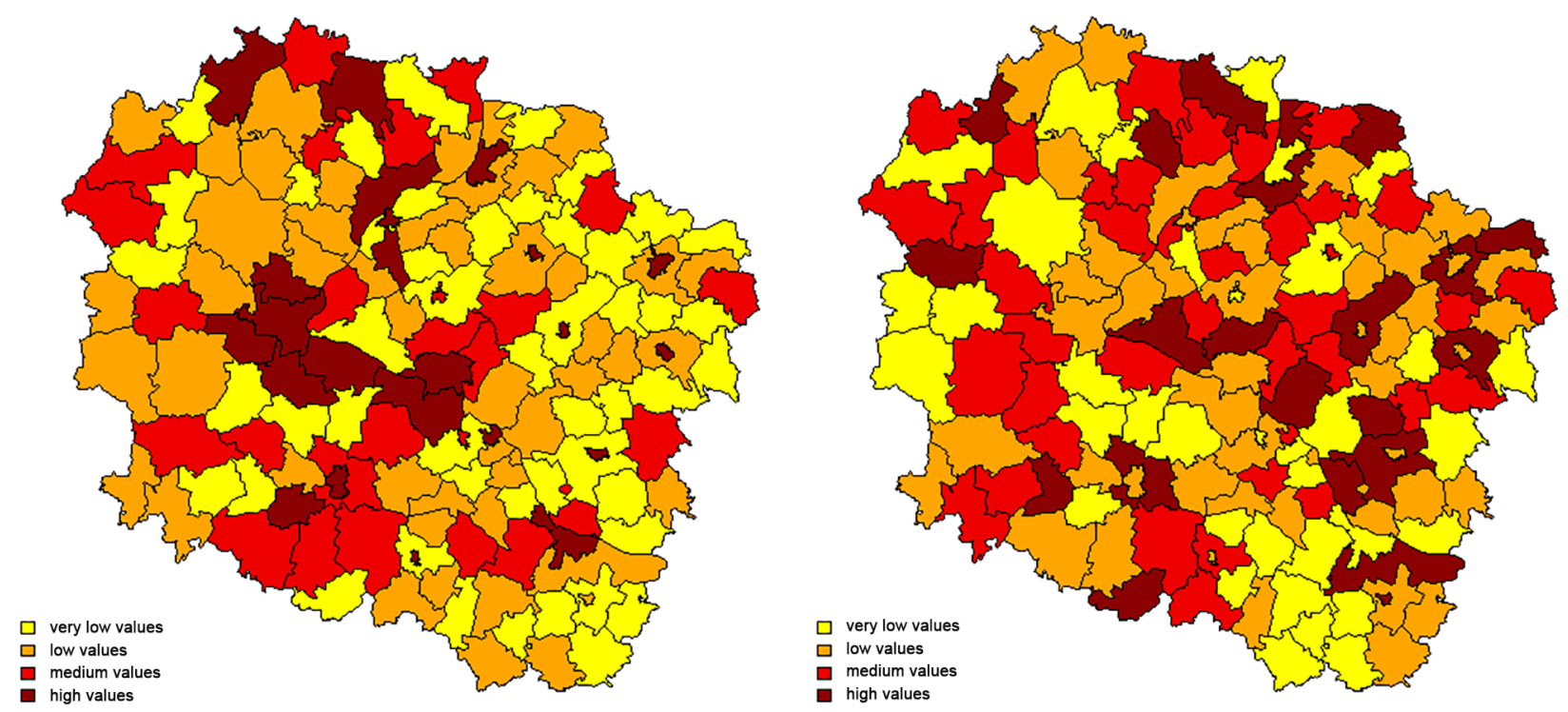

Fig. 1. Labor market situation in municipalities in 2004 and related growth rate in 2004-2015 Source: own elaboration. 

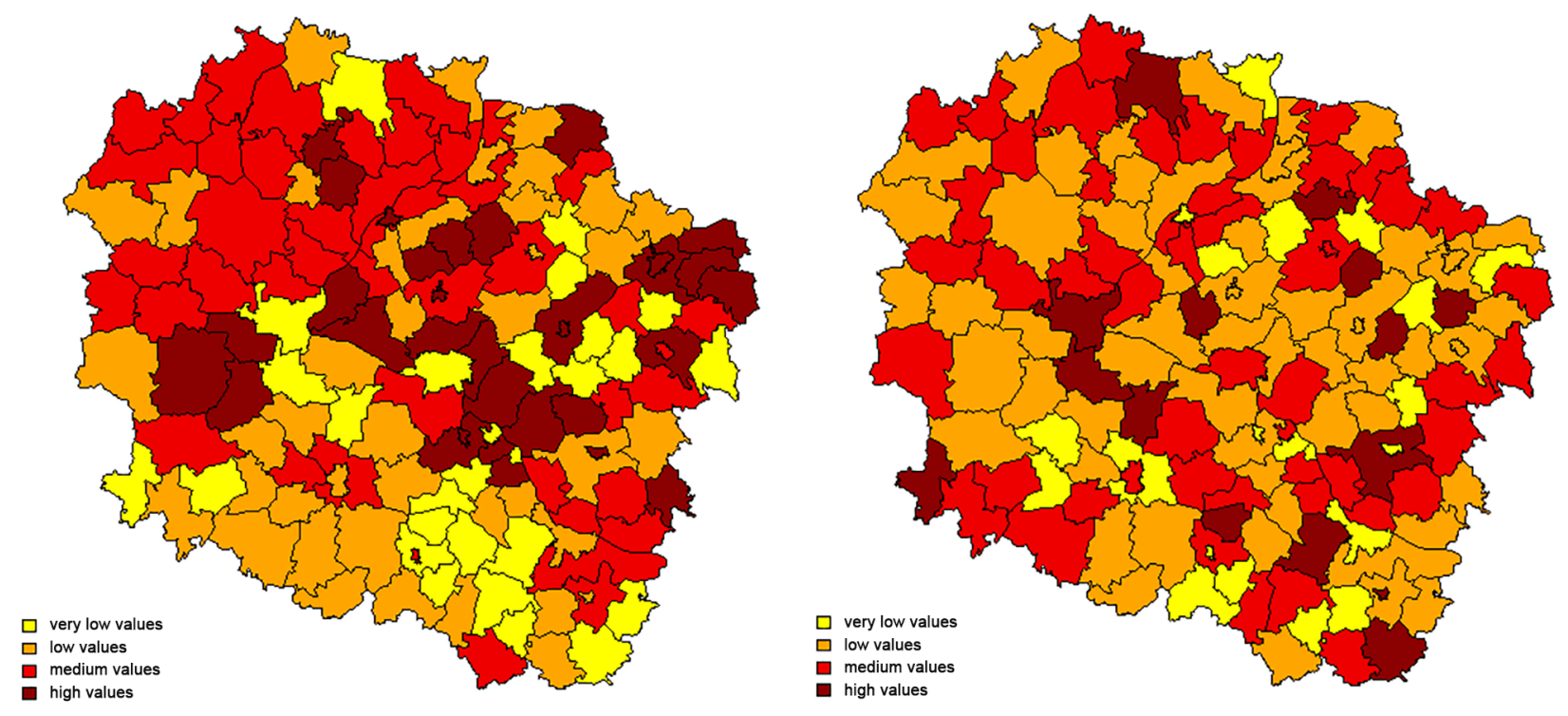

Fig. 2. Demographic situation in municipalities in 2004 and related growth rate in 2004-2015 Source: own elaboration.

Table 4. Panel diagnostic tests

\begin{tabular}{ll}
\hline \multicolumn{1}{c}{ Test } & \multicolumn{1}{c}{ Test statistics $(p$-value $)$} \\
\hline Wald & $\mathrm{F}=205.5710(0.0000)$ \\
Breusch-Pagan & $\mathrm{LM}=8369.7400(0.0000)$ \\
Hausman & $\mathrm{H}=3.7440(0.0530)$ \\
\hline
\end{tabular}

Source: own elaboration.

a synthetic spatial metric of the demographic situation in municipalities. The results of model estimation and verification are shown in Table 5.

The coefficient (parameter) of the independent variable is statistically insignificant at the 0.05 level. This means that the demographic situation in the Kujawsko-Pomorskie voivodeship, reflected by the value of the taxonomic spatial measure, does not have a significant impact on labor market situation. The insignificancy of this relationship may result from the excessive number of indicators used in the demographic situation measure. A better option could be to start by checking the relationship between the labor market situation and each of the indicators separately. The indicators can either differ in their impact on this process or be neutral. Moreover,
Table 5. Estimation and validation results for the model with fixed effects

\begin{tabular}{ccccc}
\hline Parameter & Estimate & Std. Error & $t$ statistics & $p$-value \\
\hline$\alpha$ & -0.0062359 & 0.013975 & -0.4462 & 0.6555 \\
\hline$R^{2}=0.00012577$ & $F=0.199116(0.6555)$ \\
\hline \multicolumn{5}{c}{ Breusch-Godfrey test $\chi^{2}=665.3397(0.0000)$} \\
\hline
\end{tabular}

Source: own elaboration.

the model does not demonstrate the proper characteristics of an econometric model, and therefore should be modified to better fit the reality.

The last step in this study consisted in verifying the hypothesis of reduced inequalities in the labor market. Figure 1 shows the value of the measure considered in 2004 and its growth rate in 2004-2015. It was therefore noted that in municipalities characterized by lower values of the measure, the growth rate was initially higher, and vice versa. As a consequence, it may be assumed that $\beta$-convergence occurs. Figure 2 presents the demographic situation in municipalities in 2004 and the related growth rate in 2004-2015.

The municipalities characterized by similar growth rates of both processes form a cluster but their spatial 
differentiation patterns are not similar. The municipalities with high growth rates for the labor market process do not demonstrate high growth rates of the demographic situation. It means these processes follow different paths.

The results of the estimation and verification of the convergence model for the labor market situation are presented in Table 6 .

The estimated $\beta$ parameter for the convergence model is negative at a near-critical significance level (0.05). Nevertheless, the parameter was considered statistically significant, and therefore the convergence of the labor market in the Kujawsko-Pomorskie voivodeship was examined. However, the time needed to narrow the gap by half - as calculated in the model - is nearly 72.5 years. If convergence between urban and other munici-

Table 6. Results of the estimation and verification of the convergence model for the labor market situation

\begin{tabular}{ccccc}
\hline Parameter & Estimate & Std. Error & t statistics & $p$-value \\
\hline$\alpha$ & -0.1776 & 0.0795 & -2.2220 & 0.0279 \\
$\beta$ & -0.0999 & 0.0517 & -1.9300 & 0.0556 \\
\hline \multicolumn{3}{c}{$=0.0256$} & $\mathrm{~F}(1,142)=3.7254(0.0556)$ \\
\hline \multicolumn{3}{c}{$b=0.0097$} \\
\hline \multicolumn{3}{c}{$t_{\text {half-life }}=72.4761$} \\
\hline
\end{tabular}

Source: own elaboration.

palities was considered separately, the time to narrow the gap would probably be shorter.

\section{DISCUSSION}

The high unemployment rate and poor entrepreneurship, which is observed primarily in rural areas, are the manifestations of the shortcomings in the labor market in the Kujawsko-Pomorskie voivodeship. The region also suffers from the highest degree of poverty. The adverse trend of ageing is another issue that affects the level of socio-economic development in the Kujawsko-Pomorskie voivodeship. This problem is not only affected by rural areas but by the whole region. In the past, the labor market and demographic situation was taken into account in the research on the living conditions of the rural population (Mikuła, 2013; Pomianek, 2014; Sompolska-Rzechula, 2017; Szymańska et al., 2009). In her study,
Sompolska-Rzechula (2017) points out the poor living conditions of the Kujawsko-Pomorskie voivodeship's population in comparison to other voivodeships. The analysis of the demographic conditions' impact on labor market situation was already presented in earlier literature (Mikuła, 2013; Zieliński, 2013). Zieliński (2013) states that the problem of rising unemployment is, among others, the result of increased economic activity of the population. The condition of the labor market in the $\mathrm{Ku}-$ jawsko-Pomorskie voivodeship was also discussed by Szulc and Jankiewicz (2017). According to the investigation conducted in this paper, the labor market situation in Kujawsko-Pomorskie voivodeship does not depend on the demographic situation measured with the spatial taxonomic measure of development. In this study, the demographic situation could be framed in too broad a fashion. Most earlier investigations focused on the influence of single demographic factors on the unemployment rate rather than on the general labor market situation.

The voivodeship's poor performance in the two areas referred to above also results in undermining its competitiveness compared to other European NUTS-2 regions, and in particular to other voivodeships. In his research, Hadyński (2016) used the competitiveness indicator to show that the competitiveness of the Kujawsko-Pomorskie voivodeship at the European level is quite low. However, Surówka (2014), in her interesting study, examined the competitiveness of Polish voivodeships based on several components; in this case, Kujawsko-Pomorskie was placed in the middle of the whole range. Kasztelan (2014) also conducted a research on the competitiveness of Polish voivodeships using a different approach based on the environmental point of view; in his study, Kujawsko-Pomorskie was ranked fifth.

\section{CONCLUSIONS}

The Kujawsko-Pomorskie voivodeship is very diversified in terms of labor market and demographic situation. The rural labor market needs significant development to ensure decent living conditions for the residents. The assumption that a change in the municipalities' demographic structure may improve the labor market conditions has not worked out; this issue should be addressed in more detail, based both on theoretical and econometric models. A as a part of further research on the labor market situation, the contribution of each characteristic of 
the demographic situation will be considered separately. Nevertheless, a reduction of labor market inequalities is observed, which means a (small) progress in the development of the rural labor market compared to urban areas. In further steps of this study, the research should be complemented by an approach based on dynamic panel models, developed both for the dependence of labor market conditions on demographics and for the analysis of labor market convergence. Moreover, the study should be extended to include an analysis of the urbanization process, taking into consideration the labor market situation in the Kujawsko-Pomorskie voivodeship.

\section{SOURCE OF FINANCING}

Nicolaus Copernicus University grant for young scientists: Development of rural areas of the Kujawsko-Pomorskie voivodeship in the light of the voivodship's sustainable development strategy until 2020.

\section{REFERENCES}

Antczak, E. (2013). Przestrzenny taksonomiczny miernik rozwoju [Spatial taxonomic measure of development]. Wiad. Stat., 7, 37-53.

Arbia, G. (2006). Spatial Econometrics. Statistical Foundations and Applications to Regional Convergence. BerlinHeidelberg: Springer-Verlag.

Danecka, M. (2013). Bezrobotni - niewykorzystane zasoby rynku pracy wobec problemów demograficznych. In: M. Kiełkowska (Ed.), Rynek pracy wobec zmian demograficznych (pp. 24-37). Instytut Obywatelski.

Grabiński, T. (1984). Wielowymiarowa analiza porównawcza w badaniach dynamiki zjawisk ekonomicznych. [Multidimensional comparative analysis in the study of the dynamics of economic phenomena]. Kraków: Wyd. Akademii Ekonomicznej.

Hadyński, J. (2016). Konkurencyjność regionów transgranicznych w Unii Europejskiej [The competitiveness of trans-border regions in the European Union]. Prace Nauk. Uniw. Ekon. Wroc., 433, 82-90.

Kasztelan, A. (2014). A comparative Analysis of Lubelskie and Kujawsko-Pomorskie voivodships in the context of environment al competitiveness of regions. Biul. Geogr. Socio-econ. Ser., 23(23), 87-96. https://doi.org/10.2478/ bog-2014-0006

Kolenda, M. (2006). Taksonomia numeryczna. Klasyfikacja, porządkowanie i analiza obiektów wielocechowych. Wrocław: Wyd. Akademii Ekonomicznej.

Kuc, M. (2017). The Taxonomy Spatial Measure of Development in the Standard of Living Analysis. Acta Univ.
Lodz. Folia Oecon., 1(327), 167-186. http://dx.doi. org/10.18778/0208-6018.327.10

Kusideł, E. (2013). Konwergencja gospodarcza w Polsce i jej znaczenie w osiąganiu celów polityki spójności. Łódź: Wyd. Uniwersytetu Łódzkiego.

Mikuła, A. (2013). Ubóstwo obszarów wiejskich w krajach Unii Europejskiej - demografia i rynek pracy [Poverty of rural areas in the european union member states - demography and labor market]. Prace Nauk. Uniw. Ekon. Wroc., 305, 481-491.

Osińska, M. (Ed.). (2007). Ekonometria współczesna. Torun: TNOiK.

Pietrzak, M. B. (2014). Taksonomiczny miernik rozwoju (TMR) z uwzględnieniem zależności przestrzennych [Taxonomic Measure of Development (TMD) with the Inclusion of Spatial Dependence]. Przegl. Stat., 61(2), 181-201.

Pomianek, I. (2014). Socio-economic Development of Agricultural Problem Areas in Poland. Econ. Sociol., 7(2), 218-235.

Sobolewski, M., Migała-Warchoł, A., Mentel, G. (2014). Ranking poziomu życia w powiatach w latach 2003-2012 $\mathrm{z}$ uwzględnieniem korelacji przestrzennych [Ranking the Standards of Living in Districts in Poland between 2003 and 2012 Including Spatial Correlation]. Acta Univ. Lodz. Folia Oecon., 308(6), pp. 159-172.

Sompolska-Rzechula, A. (2017). Diversification of rural areas in Poland in terms of level of living. Econ. Sci. Rural Dev. Confer. Proceed., 44, 182-189.

Suchecki, B. (Ed.) (2010). Ekonometria przestrzenna. Metody i modele analizy danych przestrzennych. Warszawa: C.H. Beck.

Surówka, A. (2014). Konkurencyjność województw Polski Wschodniej na tle regionów Unii Europejskiej w świetle badań własnych [The Competitiveness of Polish Eastern Provinces Against the Regions of the European Union in the Light of Own Studies]. Nierówn. Społ. Wzrost Gospod., 39, 394-407.

Szulc, E., Jankiewicz, M. (2017). The labour market situation in medium-sized urban centres of the Kujawsko-Pomorskie voivodeship and the problem of unemployment in the province. The 11thProfessor Aleksander Zelias International Conference on Modelling and Forecasting of Socio-Economic Phenomena. Conference Proceedings, 397-406.

Szymańska, D., Biegańska, J., Gil, A. (2009). Rural Areas in Poland in The Context of Changes in Population Age Structure in 1996, 2001 and 2006. Biul. Geogr. Socio-econ. Ser., 12(12), pp. 91-107. https://doi.org/10.2478/ v10089-009-0006-1.

Zieliński, M. (2013). Demografia i aktywność zawodowa ludności a poziom bezrobocia w Unii Europejskiej [Demography and economically active population vs. the level of unemployment im the European Union]. Prace Nauk. Uniw. Ekon. Wroc., 305, 907-916. 